\title{
Efektivitas Pendekatan Deep Learning Terhadap Kontrol Diri Remaja Dalam Menggunakan Internet
}

\author{
Nur Sya'ban Ratri Dwi Mulyani, Siti Partini Suardiman \\ ishika.mia27@gmail.com, - \\ Pascasarjana BK Universitas Negeri Yogyakarta \\ The Effectiveness Of Deep Learning Approach Towards Adolescent Self-Control
When Using Internet
}

\begin{abstract}
This study aimed to test the effectiveness of the deep learning approach in improving self-control internet usage of teenagers. This research was included in pre-experimental research with one group pre-test post-test design research. The research was conducted in SMP IT Masjid Syuhada Yogyakarta and the subjects were 20 students who lacked self-control. The data were obtained from the result of the scale used to measure the self control of internet usage. The instrument validity was determined by expert judgment. The instrument reliability was determined by Alpha Cronbach's results. The data analysis technique used t-test. The results of data analysis showed a significant change in 20 students of SMP IT Masjid Syuhada. The result of pre-test was 142.1, and the post-test was 159.6. The t-test was 9.447. There is a difference if p sig $<0.05$ and t arithmetic $>t$ table $(N 20=2.093)$. Thus, deep learning approach effectively improved self control when students of SMP IT Masjid Syuhada Yogyakarta used internet.
\end{abstract}

Keywords: Deep Learning, Self-Control, Internet

\section{Article Info}

Received date: 11 November 2018 Revised date: 27 Agustus 2019 Accepted date: 19 September 2019

\section{PENDAHULUAN}

Proses pembelajaran tidak lepas dari peran teknologi yang memfasilitasi dan mampu sebagai sumber belajar para peserta didik. Perkembangan teknologi menuntut pendidik untuk memanfaatkan teknologi dalam pembelajaran, termasuk salah satunya adalah internet. Hasil penelitian Kim menyebutkan bahwa penggunaan internet untuk tujuan pendidikan berhubungan dengan prestasi akademik (Kim, 2011). Hasil penelitian yang dilakukan lembaga PBB untuk anak-anak, UNICEF, bersama para mitra, termasuk Kementerian Komunikasi dan Informatika dan Universitas Harvard, Amerika Serikat menunjukkan sebanyak 98 persen dari anak dan remaja mengaku tahu tentang internet dan 79,5 persen di antaranya adalah pengguna internet. Beberapa motivasi yang menjadi alasan dalam menggunakan internet adalah untuk mencari informasi, untuk terhubung dengan teman dan untuk hiburan. Pencarian informasi yang dilakukan sering didorong oleh tugas-tugas sekolah, sedangkan penggunaan media sosial dan konten hiburan didorong oleh kebutuhan pribadi (Panji, 2014). Beberapa ahli di atas menyebutkan bahwa internet mampu memberikan kontribusi secara positif yang bermanfaat. Namun internet juga dapat memberikan kontribusi secara negatif jika penggunaannya tidak terkontrol. Internet yang dapat membantu orang memperoleh informasi dan hiburan ternyata juga dapat menimbulkan kecanduan (Anonim, 1999). Seorang pecandu internet akan menghabiskan waktu berjamjam atau bahkan berhari-hari untuk online menggunakan internet (Young, 1999). Sebuah berita mengungkapkan bahwa internet dapat memberikan dampak negatif kepada pelajar di Depok seperti bolos sekolah karena ingin bermain game online, mengakses video porno, dan membuat pelajar malas untuk belajar (Indopos, 2015).

Penelitian Young menunjukkan hasil bahwa kecanduan internet dapat mengakibatkan kegagalan akademik, menurunkan kinerja, perselisihan dalam perkawinan bahkan perceraian (Young, 1999). Kehadiran internet membuat seseorang cenderung asyik dengan kehidupannya sendiri. Remaja dapat asyik mengobrol melalui chatting atau melalui media sosial kapan saja. Karena terlalu asyik menggunakan internet, akhirnya remaja sering melupakan waktu belajar, sering menunda-nunda 
pekerjaan rumah dan menunda-nunda tugas yang diberikan oleh guru. Oleh karena itu perlu adanya kontrol diri pada remaja ketika menggunakan internet.

Kontrol diri dalam penggunaan internet adalah pengendalian tingkah laku dalam menggunakan internet, memanfaatkan internet dengan pertimbangan-pertimbangan tertentu, dan menggunakan internet untuk kegiatan yang positif. Dengan demikian remaja yang mampu mengontrol diri dalam menggunakan internet memiliki kemampuan untuk mengendalikan waktu dan konsumsi internet menurut kebutuhannya. Seperti misalnya menggunakan internet untuk mencari informasi dan memanfaatkan internet sebagai media sosialisasi pada waktu-waktu tertentu dan mengendalikan waktu yang dihabiskan untuk menggunakan internet.

Remaja dapat menunjukkan hal yang luar biasa dalam mengendalikan kebiasaan-kebiasaan tingkah laku namun cenderung gagal ketika ada respon positif yang mempengaruhi (Casey \& Caudle, 2013). Dengan adanya kontrol diri dalam menggunakan internet maka penggunaan internet pada diri individu akan dikendalikan secara teratur. Kontrol diri dalam menggunakan internet diharapkan akan memunculkan motivasi dan upaya untuk menggunakan internet menjadi media yang lebih bermanfaat dan adanya manajemen waktu yang baik saat internet digunakan. Kontrol diri memfasilitasi kesuksesan seseorang dalam kehidupan pada banyak bidang (Baumeister, Vohs, \& Tice, 2007). Dengan demikian penting adanya kontrol diri dalam penggunaan internet pada diri seseorang.

Fungsi kontrol terhadap penggunaan internet sendiri adalah remaja mampu mengontrol perilakunya terutama saat menggunakan internet. Remaja pada intinya mampu mengontrol penggunaan internet agar tidak mengarah pada perilaku yang sia-sia dan membuang-buang waktu seperti bermain game online dan mengakses media sosial pada waktu belajar. Dengan kontrol diri menggunakan internet remaja diharapkan dapat sukses mencapai cita-citanya. Internet dapat membantu remaja untuk belajar, mencari informasi, dan wadah sosialisasi yang bermanfaat untuk pengembangan diri remaja.

Dewi (2012) berpendapat bahwa aspek-aspek dalam kontrol diri adalah aspek behavioral control,cognitive control, decisional control. Necka (2015) menjelaskan bahwa kontrol diri terdapat ada 2 cognitive self control dan behavior self-control. Keduanya memiliki aspek yaitu menahan diri dari perilaku yang tidak sesuai, menekan pikiran, mengatasi setidaknya dua tugas yang dilakukan secara bersamaan, mengingat kewajiban dan waktu diri, mengingat rencana dan niat diri.

Remaja pada masanya masih kurang mengontrol dirinya. Saat melakukan sesuatu remaja hanya memikirkan kesenangan, mengejar kegembiraan tanpa memikirkan akibat dan resiko yang akan remaja dapatkan. Tindakan yang beresiko terjadi ketika remaja sedang berada di sekitar teman-teman mereka dan adanya rangsangan emosi (Sigelman, Rider, 2018). Remaja tidak mampu menahan emosinya dan akan mencari dorongan emosi yang kuat, dan hasilnya remaja akan berani mengambil resiko dari perbuatannya (Brier, 2015). Faktor yang mempengaruhi kontrol diri remaja salah satunya adalah teman sebaya. Teman sebaya membuat remaja berani mengambil resiko (Brier, 2015). Kontrol diri pada remaja juga dipengaruhi oleh lingkungan sekitar remaja tersebut. Ketidakcocokan antara lingkungan pendidikan dan kebutuhan psikologis pada masa remaja dapat mempengaruhi kinerja akademik dan penurunan kontrol diri remaja (Duckworth, Kim \& Tsukayama, 2013).

Menurut Haditono (2002) perkembangan moralitas remaja dibagi ke dalam 6 tingkatan yaitu, tingkatan pertama remaja mengikuti apa yang dikatakan baik atau buruk untuk memperoleh hadiah atau menghindari hukuman. Tingkatan kedua remaja memulai perkembangan moralnya. Tingkatan ketiga akan dinilai baik apa yang dapat menyenangkan dan disetujui oleh orang lain dan apa yang buruk dan tidak disetujui oleh orang lain. Tingkatan keempat adalah tumbuh semacam kesadaran akan kewajiban mempertahankan kekuasaan dan aturan-aturan yang ada dalam diri remaja, tetapi remaja belum dapat mempertanggungjawabkan secara pribadi. Tahap lima, remaja masih dapat diatur secara ketat oleh hukum-hukum umum yang lebih tinggi. Di sini remaja memiliki penilaian dari kata hati sendiri, dan belum dapat benar-benar diinternalisasikan. Dan pada tahap 6, datanglah penginternalisasian moral, yaitu remaja melakukan tingkah laku moral yang dikemudikan oleh tanggung jawab batin sendiri.

Sementara menurut Poerwanti dan Widodo (2002), perkembangan moralitas pada masa remaja telah mencapai tahap moralitas hasil interaksi seimbang yaitu secara bertahap anak mengadakan internalisasi nilai moral dari orang tuanya dan orang-orang dewasa di sekitarnya, ketika remaja mampu berpikir abstrak, remaja mulai memahami alasan berbuat baik dan buruk tersebut dan mampu berbuat moralistik secara mandiri.

Pada dasarnya remaja memiliki kesadaran akan kontrol diri di dalam dirinya namun beberapa juga menunjukkan kegagalan dalam kontrol dirinya. Remaja dapat menunjukkan hal yang luar biasa 
dalam mengendalikan kebiasaan-kebiasaan tingkah laku namun cenderung gagal ketika ada respon positif yang mempengaruhi (Casey \& Caudle, 2013). Beberapa tantangan dalam diri remaja saat mengontrol diri dalam menggunakan internet juga harus dihadapi oleh remaja. Remaja ditempatkan pada posisi memutuskan sendiri apa yang dimaksud dengan informasi yang baik, dan apa yang tidak (Suler, 2005). Beberapa informasi dan keterampilan yang mungkin dicari remaja lebih baik dibiarkan begitu saja. Pornografi, obat-obatan, metode kekerasan semuanya ada di internet (Suler, 2005). Kebebasan informasi, kontrol informasi, dan nilai-nilai yang memengaruhi sikap adalah semua masalah yang semua orang harus hadapi. Oleh karena itu perlu adanya peningkatan kontrol diri dalam diri remaja. Hal ini diperlukan agar remaja berfikir kembali dan mampu memisahkan mana yang baik dan mana yang berakibat buruk.

Dzulkifli (2005) mengatakan bahwa karakteristik perkembangan sosial remaja ditandai dengan remaja lebih terikat dengan kelompok, yaitu tertarik kepada kelompok sebayanya dan lebih memilih untuk bergabung dengan kelompok sebayanya yang dianggap lebih mengerti, apalagi jika memiliki pengalaman yang sama dibandingkan keluarganya.

Sedangkan menurut Haditono, dkk (2002) pada masa remaja perkembangan dalam aspek sosial ditunjukkan dengan timbulnya kelompok-kelompok, perkumpulan-perkumpulan untuk bermain bersama atau membuat rencana bersama. Suatu sifat yang khas lagi dari kelompok anak pra-remaja atau pubertas ini adalah bahwa mereka tidak menentang orang dewasa, melainkan justru menirukan mereka dalam olah raga, permainan dan kesibukan-kesibukan yang lain.

Dari beberapa paparan pendapat para ahli, dapat disimpulkan bahwa perkembangan sosial remaja ditunjukkan dengan adanya kelompok-kelompok, perkumpulan yang memiliki tujuan bersama, memiliki nilai khas kelompok sendiri, mempunyai tingkat solidaritas yang tinggi. Selain itu, perkembangan sosial remaja dapat ditunjukkan dengan ketertarikannya dengan lawan jenis, dan kemampuannya dalam pemilihan karir di masa depan.

Karakteristik kontrol diri pada remaja berkaitan dengan moral dan pengendalian diri pada sikap dan perilaku remaja. Kaitannya pada moral adalah remaja masih mengikuti keinginannya berdasarkan kesenangan saja, menuruti kata hati sendiri, dan kurang mampu bertanggung jawab. Namun beberapa remaja sudah mampu untuk memahami manakah hal yang baik dan buruk bagi diri remaja. Kaitannya dengan kontrol diri terhadap penggunaan internet beberapa remaja masih mengikuti keinginannya tanpa tahu dampak penggunaan internet. Dapat didefinisikan bahwa remaja masih kurang mempertimbangkan segala sesuatu yang baik bagi diri sendiri. Pada tingkat hubungan sosial remaja juga cenderung lebih terikat dengan kelompok. Kontrol diri pada remaja juga dipengaruhi oleh lingkungan. Oleh karena itu penggunaan internet pada remaja juga distimulasi oleh teman sebaya yang mengajak untuk menggunakan internet pada waktu belajar. Perlu adanya peningkatan kontrol diri dalam diri remaja. Hal ini diperlukan agar remaja berfikir kembali dan mampu memisahkan mana yang baik dan mana yang berakibat buruk.

Deep learning adalah proses konstruksi pengetahuan permanen dimana ketika peserta didik menghadapi masalah atau sebuah pertanyaan, peserta didik akan merasakan konflik kognitif yang berasal dari interaksi sosial dengan teman sebaya sehingga peserta didik akan merasa termotivasi untuk menyelesaikannya (Hermida, 2015). Karakteristik deep learning adalah: membuat peserta didik aktif berusaha untuk memahami materi atau subyek, berinteraksi dengan penuh semangat, mampu memanfaatkan sumber-sumber yang telah diberikan dan mengevaluasi seberapa besar pengaruhnya, mampu mengambil pandangan yang luas, menghubungkan ide satu dengan yang lain, mengaitkan ideide baru bagi pengetahuan sebelumnya, berkaitan dengan konsep kehidupan sehari-hari, cenderung untuk membaca dan belajar di luar (Lublin, 2003). Deep learning dalam belajar ditandai dengan niat untuk memahami dan melihat makna, mengarahkan siswa untuk mencoba menghubungkan konsep pemahaman yang ada dan satu sama lainnya, untuk membedakan antara ide-ide baru dan pengetahuan yang ada, dan untuk mengevaluasi secara kritis dan menentukan tema dan konsep-konsep kunci (Fry, Ketteridge, Marshall, 2009). Karakteristik pendekatan deep learning ditandai dengan niat dalam belajar untuk memahami materi pembelajaran, mencari makna dan memahami ide-ide di dalamnya. Siswa yang menggunakan pendekatan deep learning mencari prinsip-prinsip dasar dan usaha untuk menghubungkan pengetahuan sebelumnya dan pemahaman. Siswa akan mempertanyakan logika dan argumen (Moon, 2005). Di dalam pendekatan deep learning terdapat tujuan untuk mengambil makna. Pendekatan deep learning menghasilkan proses pembelajaran aktif dan melibatkan ide-ide yang berkaitan dan mencari pola dan prinsip-prinsip di satu sisi. Pendekatan deep learning mencari makna 
didukung dengan menggunakan bukti dan pemeriksaan logika argumen (Enwistle, 2000). Pendekatan deep learning secara intrinsik lebih memotivasi siswa dan melakukan kegiatan belajar yang bermakna. Memotivasi peserta didik untuk mencari nilai yang berarti dan untuk memotivasi diri mereka sendiri untuk belajar. (Moore dan Telfer, 1990). Pendekatan deep learning didasari dengan keterlibatan individual terhadap proses belajar, pengetahuan yang memadai dan keingintahuan yang tinggi mengenai materi pelajaran. (Ganda, Ngwakwe, Ambe, 2014).

Aspek lain dari Pendekatan deep learning antara lain tugas yang terfokus, peserta didik belajar untuk memahami konten yang dipelajari, mencari materi secara luas, menghasilkan tingkat pemahaman yang dalam, membentuk kembali pemikiran baru dalam materi pelajaran, secara kritis menghubungkannya dengan pengalaman dan ide lain, mengintegrasikan pengetahuan formal dengan pengalaman individu, menghubungkan fakta dengan kesimpulan (Hasnora, Ahmadb, \&Nordin, 2013)

Langkah-langkah yang dilakukan dalam pendekatan deep learning menurut Sukarno (2013) adalah sebagai berikut memahami standar kandungan materi, mengidentifikasi karakteristik peserta didik, melihat kesiapan belajar peserta didik, merencanakan pembelajaran, mengadakan proses pembelajaran, menilai tampilan peserta didik.

Kompetensi yang dikembangkan dalam pendekatan deep learning, yang merupakan kunci masa depan menurut Seam (2014) diantaranya adalah pendidikan karakter, kejujuran, tanggung jawab, kerja keras, empati dan kepercayaan diri, kesehatan pribadi, karir, dan keterampilan. Kewarganegaraan, pengetahuan secara umum, sensitivitas dan peduli terhadap kebudayaan orang lain. Komunikasi, mengkomunikasikan secara efektif saat menulis, dan keterampilan mendengarkan. Berfikir kritis, dan memecahkan masalah, berfikir kritis untuk membuat dan mengelola proyek, menyelesaikan masalah, membuat keputusan yang efektif menggunakan variasi sumber digital. Kolaborasi, bekerja dalam tim, belajar dari dan berkontribusi pada pembelajaran,keterampilan sosial, empati pada perbedaan. Kreativitas dan imajinasi, kewirausahaan ekonomi dan sosial, mempertimbangkan dan menunjukkan ide, dan kepemimpinan.

Jensen dan Nickelsen (2008) menyebutkan langkah-langkah pendekatan deep learning adalah; merencanakan standar dan kurikulum, melakukan pra penilaian, membangun budaya pembelajaran yang positif, menggali dan mengaktivasikan pengetahuan sebelumnya, memperoleh pengetahuan baru, mengolah pembelajaran lebih dalam, mengevaluasi pembelajaran peserta didik. Lublin (2003) menyebutkan teknik dalam pendekatan deep learning adalah workload, assessment and learning objective, teaching, choice, jigsaw using a graphic organizer, cooperative debates, pro-con-caveat grid. Dalam penelitian ini diharapkan nantinya pendekatan deep learning mampu meningkatkan motivasi siswa melalui aspek berfikir kritis pada setiap permasalahan terutama menyangkut tentang kontrol diri dalam penggunaan internet.

\section{METODE PENELITIAN}

Desain yang dipilih dalam penelitian ini adalah one group pre-test post-test. Peneliti mengambil subyek penelitian sebanyak 20 siswa. Penelitian ini dilaksanakan di SMP IT Masjid Syuhada Yogyakarta. Penentuan subjek penelitian dalam penelitian ini menggunakan teknik purposive sampling. Variabel bebas dalam penelitian ini adalah pendekatan deep learning. Variabel terikat dalam penelitian ini adalah kontrol diri peserta didik terhadap penggunaan internet. Teknik pengumpulan data yang digunakan dalam penelitian ini adalah teknik non tes. Data diperoleh dari skala kontrol diri terhadap penggunaan internet. Instrumen skala kontrol diri ini diberikan kepada siswa saat pretest dan posttest dalam penelitian.

Di dalam penelitian ini ada beberapa prosedur yang akan dilakukan. Beberapa prosedur atau langkah-langkah yang akan dilakukan dalam penelitian ini adalah sebagai berikut:

a. Sebelum Perlakuan Diberikan: Menyiapkan instrumen berupa skala kontrol diri dalam menggunakan internet, dan menyiapkan media yang diperlukan saat pemberian perlakuan, menentukan sampel penelitian berdasarkan hasil skala kontrol diri terhadap penggunaan internet, diambil sampel penelitian yang memiliki skor kontrol diri yang kurang diantara siswa yang lain, melakukan pre-test tingkat kontrol diri pada siswa dengan menggunakan skala kontrol diri terhadap penggunaan internet, menganalisis hasil pre-test tingkat kontrol diri, merancang kegiatan bimbingan dengan menggunakan pendekatan deep learning. 
b. Pemberian Perlakuan: Melaksanakan pertemuan yang pertama yaitu peneliti memberikan penjelasan informasi tentang pentingnya kontrol diri dalam menggunakan internet, tips menggunakan internet dengan sehat, dan bahaya kecanduan internet. Peneliti menggunakan media power point dan video dalam menjelaskan informasi. Teknik ini bertujuan untuk memberikan pemahaman kepada siswa tentang bahaya kecanduan internet, dan tips menggunakan internet dengan sehat. Kegiatan diakhiri dengan refleksi dan menyimpulkan secara bersama-sama informasi yang telah diperoleh. Melaksanakan pertemuan yang kedua yaitu,menganalisis kasus penggunaan internet pada remaja. Analisis kasus yang dilakukan adalah analisis kasus tentang dampak penggunaan internet secara positif maupun secara negatif. Teknik ini bertujuan untuk menjelaskan kepada siswa lebih mendalam tentang dampak internet secara positif ataupun negatif melalui pengalaman dari beberapa peristiwa.Kegiatan diakhiri dengan refleksi dan menyimpulkan bersama kesimpulan yang diperoleh dari beberapa kasus yang telah disampaikan. Melaksanakan pertemuan yang ketiga yaitu, siswa mengerjakan tabel perbandingan dampak buruk dan dampak baik dalam menggunakan internet. Teknik ini bertujuan untuk memperdalam kembali informasi yang telah disampaikan dan mengetahui sejauh mana pemahaman siswa mengenai informasi yang sudah disampaikan. Melaksanakan pertemuan yang keempat yaitu siswa memerankan beberapa tokoh dalam sebuah naskah cerita. Teknik ini bertujuan untuk memberikan pemahaman kepada siswa tentang penggunaan internet yang bermanfaat dan penggunaan internet yang kurang bermanfaat. Kegiatan diakhiri dengan refleksi dan menyimpulkan bersama-sama kesimpulan yang dapat diambil setelah kegiatan dilakukan.

c. Setelah Perlakuan Diberikan: Menganalisis hasil skala post-test kontrol diri terhadap penggunaan internet. Menyajikan hasil analisis data dalam bentuk diagram dan tabel.

Uji validitas terhadap instrument ditentukan dari validitas konstruk. Validitas instrument kemudian dianalisis menggunakan korelasi Product Moment. Item dikatakan valid jika $\mathrm{r}$ hitung $>\mathrm{r}$ tabel $(\mathrm{N}=50$ lihat $\mathrm{r}$ tabel $5 \%=0,279$ atau $\mathrm{p}$ sig <0,05). Peneliti menganalisis uji reliabilitas instrument menggunakan SPSS. Dikatakan reliabel jika alpha cronbach $>0,70$ semakin mendekati 1,0 semakin tinggi reliabelnya. Uji normalitas data dilakukan dengan menggunakan uji kologrov smirnov. Data dikatakan normal jika p sig >0,05. Data kemudian diuji homogenitas menggunakan uji levene test. Data dikatakan homogen jika $\mathrm{p}$ sig $>0,05$. Teknik analisis data yang digunakan adalah uji-t. Analisis tersebut dilakukan terhadap data yang diperoleh dari angket pre-test dan post-test. Syarat penggunaan uji-t adalah sebaran data berdistribusi normal serta variabel pre-test dan post-test homogen. Data dikatakan ada perbedaan jika $\mathrm{p}$ sig $<0,05$ dan $\mathrm{t}$ hitung $>\mathrm{t}$ tabel $(\mathrm{N} 20=2,093)$.

\section{HASIL DAN PEMBAHASAN}

Hasil

Peneliti mendapatkan hasil perhitungan sebagai berikut:

Tabel 1. Data Hasil Pre-Test Kontrol Diri

\begin{tabular}{|c|c|c|}
\hline & & Pretest \\
\hline$N$ & Valid & 20 \\
\hline iv & Missing & 0 \\
\hline $\mathrm{Mc}$ & & 143,5 \\
\hline & & 142,0000 \\
\hline & & 142,00 \\
\hline & viation & 4,16091 \\
\hline & & 136,00 \\
\hline & & 151,00 \\
\hline & & Sedang \\
\hline
\end{tabular}

Tabel di atas menunjukkan bahwa skor rata-rata (mean) sebesar 143,5 dengan kategori sedang. Hasil pre-test menunjukkan bahwa sebanyak 20 siswa memiliki kontrol diri pada kategori sedang dengan skor minimal 136 dan skor maksimal adalah 151. Peneliti mendapatkan hasil perhitungan posttest sebagai berikut: 
Efektivitas Pendekatan Deep Learning Terhadap Kontrol Diri Remaja Dalam Menggunakan Internet (Nur Sya'ban Ratri Dwi Mulyani, Siti Partini Suardiman)

Tabel 2. Data Hasil Post-Test Kontrol Diri

\begin{tabular}{|c|c|c|}
\hline \multicolumn{3}{|c|}{ Kontrol Diri Posttest } \\
\hline \multirow{2}{*}{$\mathrm{N}$} & Valid & 20 \\
\hline & Missing & 0 \\
\hline \multicolumn{2}{|c|}{ Mean } & 159,6 \\
\hline \multicolumn{2}{|c|}{ Median } & 160,5000 \\
\hline \multicolumn{2}{|c|}{ Mode } & 162,00 \\
\hline \multicolumn{2}{|c|}{ Std. Deviation } & 6,72368 \\
\hline \multicolumn{2}{|c|}{ Minimum } & 148,00 \\
\hline \multicolumn{2}{|c|}{ Maximum } & 172,00 \\
\hline \multicolumn{2}{|c|}{ Kategori } & Tinggi \\
\hline
\end{tabular}

Tingkat kontrol diri dalam menggunakan internet berada pada kategori tinggi. Skor rata-rata pada post-test adalah sebesar 159,6. Hasil post-test menunjukkan bahwa ada perubahan yang signifikan. Pada tabel dapat dilihat bahwa terdapat perubahan skor hasil post-test sebanyak 18 siswa memiliki skor yang berkategori tinggi, dan 2 siswa memiliki skor berkategori sedang. Skor minimal hasil post-test siswa adalah sebesar 148 dan skor maksimal hasil post-test siswa adalah sebesar 172. Perbandingan hasil skor rata-rata pada saat sebelum perlakuan dilakukan (pre-test) dan setelah perlakuan diberikan (post-test) dapat dilihat pada gambar berikut ini:

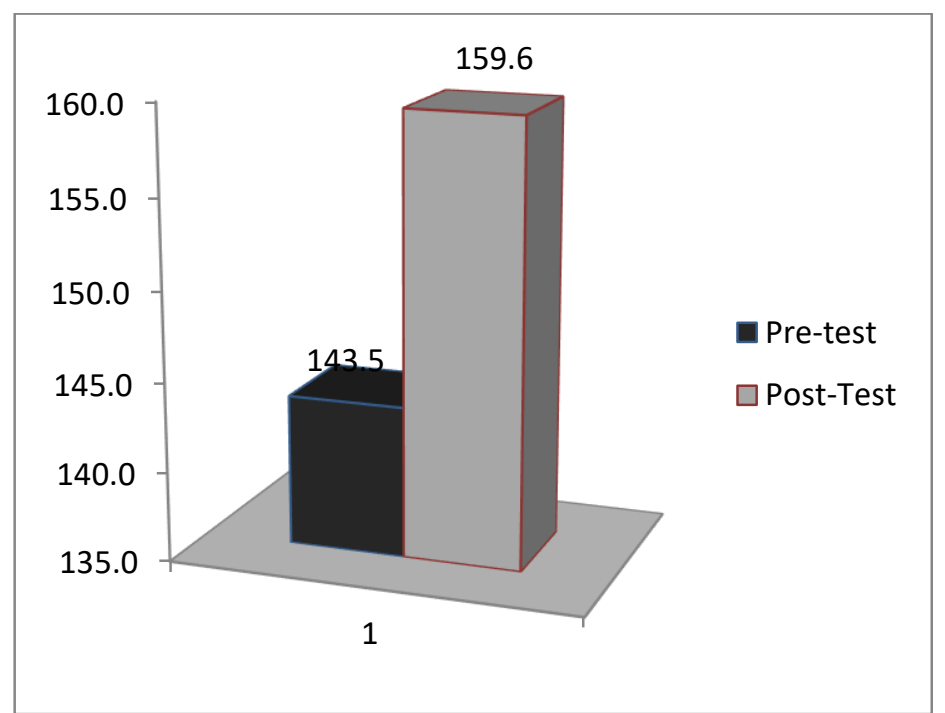

\section{Gambar 1. Perbandingan Hasil Skor rata-rata Pre-test dan Post-test}

Sebelum menganalisis $t$-test, uji normalitas dan uji homogenitas pada data dilakukan terlebih dahulu. Berikut pemaparan hasil analisisnya.

Tabel 3. Hasil Uji Normalitas Data Pre-Test

\begin{tabular}{|ll|r|}
\hline & & \multicolumn{2}{|c|}{ Kontrol Diri Pretest } \\
\hline N & Mean & 20 \\
Normal Parameters & Stb. & 143,4500 \\
& Deviation & 4,16091 \\
Most Extreme & Absolute &, 186 \\
Differences & Positive &, 186 \\
Kolmogorov-Smirnov Z & Negative & -103 \\
Asymp. Sig. (2-tailed) &, 833 \\
\hline
\end{tabular}


Tabel 4. Hasil Uji Normalitas Data Post-Test

\begin{tabular}{|ll|r|}
\hline & & \multicolumn{2}{|c|}{ Kontrol Diri Posttest } \\
\hline N & Mean & 20 \\
Normal Parameters & Std. & 159,5500 \\
& Deviation & 6,72368 \\
Most Extreme & Absolute &, 167 \\
Differences & Positive &, 135 \\
Kolmogorov-Smirnov Z & Negative &,- 167 \\
Asymp. Sig. (2-tailed) &, 749 \\
\hline
\end{tabular}

Pada tabel 3 dapat dilihat bahwa hasil data pre-test normal. Data dikatakan normal jika p sig > 0,05 . Hasil pre-test menunjukkan bahwa p sig $>0,05(0,492)$.Pada tabel 4 juga dapat dilihat bahwa hasil data post-test normal. Data dikatakan normal jika p sig $>0,05$. Hasil post-test $\mathrm{p}$ sig $>0,05(0,629)$.

Setelah dilakukan uji normalitas data, selanjutnya dilakukan uji homogenitas data. Hasil dari uji homogenitas data adalah sebagai berikut:

Tabel 5. Hasil Uji Homogenitas Data

\begin{tabular}{|c|c|c|c|c|}
\hline & Levene Statistic & df1 & df2 & Sig. \\
\hline Kontrol diri & 2,933 & 1 & 38 & 0,095 \\
\hline
\end{tabular}

Data dikatakan homogen jika p sig $>0,05$. Hasil uji homogenitas data menunjukkan bahwa data homogen ( $\mathrm{p}$ sig > 0,05). Dari beberapa hasil uji di atas, data diketahui normal dan homogen. Berikut ini adalah tabel perbandingan hasil t-test kontrol diri sebelum perlakuan (pre-test) dan setelah perlakuan (post-test):

Tabel 6. Data Hasil Perbandingan Hasil t-test Kontrol Diri

\begin{tabular}{llrrrr}
\hline & & Mean & N & Std. Deviation & Std. Error Mean \\
\hline \multirow{2}{*}{ Pair } & Kontrol Diri Posttest & $\mathbf{1 5 9 , 6}$ & 20 & 6,72368 & 1,50346 \\
\cline { 2 - 6 } & Kontrol Diri Pretest & $\mathbf{1 4 3 , 5}$ & 20 & 4,16091 &, 93041 \\
\hline
\end{tabular}

Pada tabel 6 data menunjukkan bahwa terdapat peningkatan hasil setelah perlakuan diberikan.Data pre-test menunjukan rata-rata skor adalah 143,5 setelah mendapatkan perlakuan (posttest) skor rata-rata meningkat menjadi 159,6. Berikut selisih perbandingan rata-rata sebelum perlakuan (pre-test) dan setelah perlakuan (post-test).

Tabel 7. Data Selisih Perbandingan Rata-rata Pre-test dan Post-test

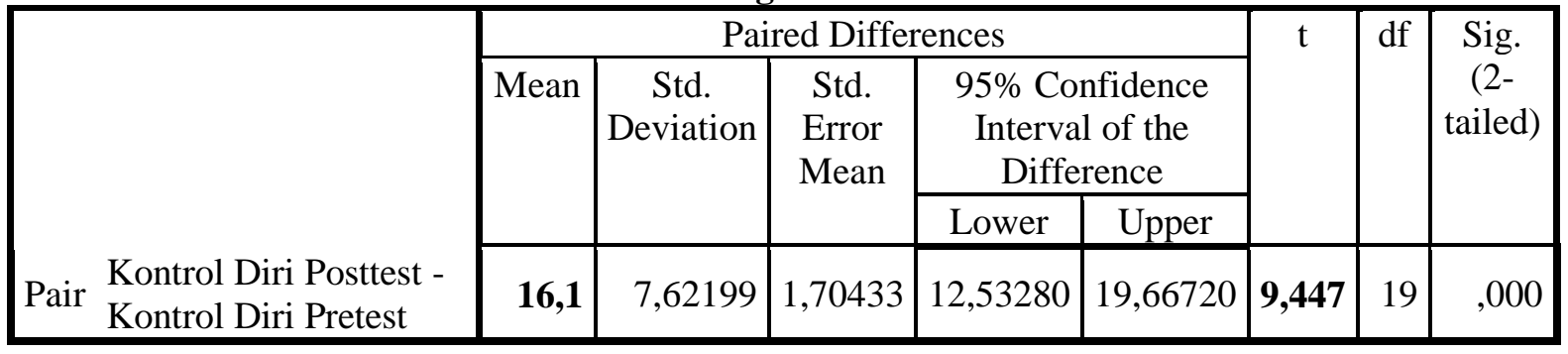

Pada tabel 7 dapat diketahui bahwa selisih perubahan cukup signifikan.Selisih perubahan antara pre-test dan post-test adalah 16,1. Hasil $t$-test menunjukkan bahwa terdapat perubahan signifikan pada subyek. Dikatakan ada perbedaan jika p sig < 0,05 dan $\mathrm{t}$ hitung $>\mathrm{t}$ tabel $(\mathrm{N} 20=2,093)$. Pada tabel 7 dapat dilihat hasil $\mathrm{t}$ hitung pada post-test $>\mathrm{t}$ tabel yaitu 9,447.

Pembahasan

Kontrol diri dalam menggunakan internet mengukur kemampuan seseorang mengendalikan waktu yang dihabiskan untuk internet (Highfield, 2012). Dengan demikian remaja yang mampu 
mengontrol diri dalam menggunakan internet memiliki kemampuan untuk mengendalikan waktu dan konsumsi internet menurut kebutuhannya. Kontrol diri memfasilitasi kesuksesan seseorang dalam kehidupan pada banyak bidang (Baumeister, Vohs, \& Tice, 2007). Dengan adanya kontrol diri dalam menggunakan internet maka penggunaan internet pada diri individu akan dikendalikan secara teratur. Kontrol diri dalam menggunakan internet diharapkan akan memunculkan motivasi dan upaya untuk menggunakan internet menjadi media yang lebih bermanfaat dan adanya manajemen waktu yang baik saat internet digunakan.

Faktor-faktor dari kontrol diri meliputi lingkungan internal serta eksternal (Larasati dan Budiani, 2014). Motivasi juga berperan dalam pembentukan kontrol diri (Muraven \& Slessareva, 2003). Adanya hubungan yang berkesinambungan antara kemauan dan kontrol diri. Individu yang dapat menjalankan kemauan secara teratur maka akan meningkatkan kontrol diri individu tersebut (Weir, 2012). Ghufron dan Risnawita (2010) juga mengungkapkan bahwa salah satu faktor eksternal yang mempengaruhi kontrol diri seorang individu adalah lingkungan keluarga. Jadi faktor yang mempengaruhi kontrol diri dalam menggunakan internet adalah terdapat dua yaitu faktor internal dan faktor eksternal. Faktor internalnya adalah usia, yakni semakin bertambahnya usia maka kontrol diri semakin matang, motivasi, kemauan, dan keyakinan. Untuk faktor eksternal adalah lingkungan di sekitar individu seperti keluarga.

Dewi (2012) berpendapat bahwa aspek-aspek dalam kontrol diri adalah aspek behavioral control,cognitive control, decisional control. Dari pendapat Dewi behavioral control dapat diartikan sebagai kontrol perilaku. Sedangkan cognitive control adalah kontrol kognitif. Dan decisional control dapat diartikan sebagai kontrol dalam membuat keputusan. Larasati dan Budiani (2014) menyebutkan bahwa aspek kontrol diri adalah behavioral control, cognitive control, dan decisional control. Necka (2015) menjelaskan bahwa kontrol diri terdapat ada 2 cognitive self control dan behavior self-control.

Kontrol diri dapat mengubah diri seseorang menjadi lebih baik secara optimal sehingga seseorang dapat beradaptasi dengan baik dengan lingkungan sosial (Tangney, Baumeister, \& Boone, 2004). Kontrol diri sangat berpengaruh terhadap remaja. Kontrol diri berfungsi untuk mengontrol pengaruh agresi pada remaja. Pengaruh agresi di sini yang dimaksudkan adalah pengaruh perilaku agresi pada remaja. Kontrol diri menekan dorongan untuk berbuat agresi dan berbuat kejahatan (Pung, Yaacob, Baharudin dan Osman, 2015). Kontrol diri penting karena membantu siswa dapat diandalkan ketika kelas di antaranya adalah memulai pekerjaan rumah mereka lebih awal, dan menghabiskan banyak waktu untuk bekerja dan lebih sedikit waktu untuk menonton televisi (Baumeister dan Tierney, 2011). Kontrol diri membantu orang menahan godaan yang beragam seperti cokelat, video game, belanja, dan hal lainnya (McGonigal, 2012). Kontrol diri dapat mendorong seseorang memiliki motivasi untuk meraih keberhasilan dalam hidupnya. Kontrol diri membuat seseorang memiliki hasil yang positif dalam kehidupan (Tangney, Baumeister, \& Boone, 2004).

Di dalam proses penelitian siswa aktif selama proses kegiatan berlangsung. Beberapa siswa memiliki pengalaman yang berbeda di dalam menggunakan internet. Hal tersebut dapat memberikan gambaran fakta dan obyektif serta bukti sehingga pemahaman siswa akan lebih mendalam. Diskusi di dalam kelompok membangun komunikasi yang efektif karena muncul ide-ide baru yang membantu pemahaman siswa dalam pemecahan masalahnya. Kegiatan peserta didik tidak hanya berkaitan dengan teori melainkan juga dengan praktik dan menuntut keaktifan dalam pembelajaran. Pembelajaran yang dilakukan menggunakan pendekatan deep learning dimana didalamnya terdapat interaksi antara guru dengan peserta didik.

Peneliti menerapkan karakteristik menghubungkan fakta-fakta, ide-ide dan konsep dalam menafsirkan, mengusulkan atau menilai, mengusulkan elemen baru dalam informasi, membuat informasi baru dari informasi yang dikumpulkan, menggunakan hipotesis dan kutipan, mengusulkan satu atau lebih solusi dalam hal penilaian, mengasumsikan keuntungan dan kerugian situasi atau solusi, menyajikan dukungan bukti dengan contoh-contoh. Salah satu contohnya pada perlakuan yang kedua peneliti melakukan brainstorming untuk mengulang informasi pada kegiatan sebelumnya. Informasi tersebut dihubungkan dengan informasi dan kesimpulan setelah perlakuan kedua. Pada pertemuan pertama peneliti memberikan informasi melalui video sebagai bukti dan contoh kurangnya kontrol diri dalam menggunakan internet dapat memberikan beberapa dampak. Informasi tersebut dapat digunakan siswa untuk mengembangkan sebuah strategi baru bagaimana mengontrol diri dalam menggunakan internet. Pada pertemuan kedua siswa disuguhkan beberapa kasus untuk dianalisis kemudian dipahami apa makna dari kasus tersebut yang berkaitan dengan kontrol diri. Pada pertemuan ketiga peneliti 
memberikan tabel perbandingan antara dampak positif dan dampak negatif dari penggunaan internet sehingga siswa memahami bahwa internet mampu memberikan aspek positif jika mampu mengontrol diri saat menggunakan internet. Pada pertemuan keempat siswa melakukan psikodrama sehingga siswa merasakan bagaimana jika seseorang tidak dapat mengontrol diri saat menggunakan internet. Beberapa pertemuan tersebut mengintegrasikan aspek kognitif dan mengeksperimenkannya di dalam pengalaman sehingga pemahaman secara mendalam pada siswa dapat terwujud.

Aspek dari pendekatan deep learning adalah, tugas yang terfokus, peserta didik belajar untuk memahami konten yang dipelajari, mencari materi secara luas, menghasilkan tingkat pemahaman yang dalam, membentuk kembali pemikiran baru dalam materi pelajaran, secara kritis menghubungkannya dengan pengalaman dan ide lain, mengintegrasikan pengetahuan formal dengan pengalaman individu, menghubungkan fakta dengan kesimpulan (Hasnora, Ahmadb , Nordin, 2013). Pendekatan deep learning tidak hanya menuntut seseorang untuk memahami secara kognitif saja, melainkan juga mengintegrasikannya di dalam pengalaman seseorang sehingga mewujudkan pemahaman yang mendalam pada seseorang. Salah satu faktor dalam kontrol diri dalam menggunakan internet adalah motivasi. Pendekatan deep learning secara intrinsik lebih memotivasi siswa dan melakukan kegiatan belajar yang bermakna. Memotivasi peserta didik untuk mencari nilai yang berarti dan untuk memotivasi diri mereka sendiri untuk belajar.(Moore\& Telfer, 1990). Sesuai dengan pendapat tersebut, peneliti bermaksud meningkatkan motivasi siswa sehingga meningkat juga kontrol diri dalam menggunakan internet pada diri siswa.

Fungsi kontrol terhadap penggunaan internet sendiri adalah remaja mampu mengontrol perilakunya terutama saat menggunakan internet. Remaja pada intinya mampu mengontrol penggunaan internet sehingga tidak mengarah pada perilaku yang sia-sia dan membuang-buang waktu seperti bermain game online dan mengakses media sosial pada waktu belajar.

\section{PENUTUP}

Hasil $t$-test menunjukkan bahwa terdapat perubahan signifikan pada subyek. Dikatakan ada perbedaan jika p sig $<0,05$ dan $\mathrm{t}$ hitung $>\mathrm{t}$ tabel $(\mathrm{N} 20=2,093)$. Hasil $\mathrm{t}$ hitung pada post-test $>\mathrm{t}$ tabel yaitu 9,447. Dengan demikian pendekatan deep learning efektif meningkatkan kontrol diri dalam menggunakan internet siswa SMP IT Masjid Syuhada Yogyakarta. Pendekatan deep learning menghubungkan fakta-fakta, ide-ide dan konsep dalam menafsirkan, mengusulkan atau menilai, mengusulkan elemen baru dalam informasi, membuat informasi baru dari informasi yang dikumpulkan. Dengan demikian siswa dapat mengembangkan strategi bagaimana mengontrol diri ketika menggunakan internet dan mengetahui hal yang paling penting yang berpengaruh dalam mengontrol dirinya saat menggunakan internet. Berdasarkan hasil penelitian, pembahasan, kesimpulan, dan implikasi penelitian di atas, maka diajukan saran-saran sebagai berikut:

1. Mahasiswa Bimbingan dan Konseling dapat menerapkan teknik-teknik pendekatan deep learning sebagai salah satu cara mengubah tingkat kontrol diri dalam menggunakan internet.

2. Konselor sekolah atau praktisi Bimbingan dan Konseling dapat menggunakan pendekatan deep learning sebagai salah satu teknik bimbingan untuk mengubah kontrol diri dalam menggunakan internet pada diri individu.

3. Para peneliti dan pengembang keilmuan Bimbingan dan Konseling perlu menyelenggarakan penelitian pengembangan atau penelitian lanjutan tentang efektivitas pendekatan deep learning terhadap variabel lain selain kontrol diri dalam menggunakan internet.

\section{UCAPAN TERIMA KASIH}

Penulis menyampaikan ucapan terima kasih kepada:

1. Ibu Prof. Dr. Siti Partini Suardiman, Pembimbing penelitian yang dengan sabar dan ikhlas meluangkan waktu untuk memberikan bimbingan, arahan serta petunjuk yang sangat berharga.

2. Ibu Ade Syarifah, S. Pd. guru Bimbingan dan Konseling SMP IT Syuhada Yogyakarta yang telah memberikan arahan dalam pengembangan penelitian.

3. Ibu Yuli Nurfahmi, S. Pd. guru Bimbingan dan Konseling SMP IT Syuhada Yogyakarta yang telah memberikan arahan dalam pengembangan penelitian. 
Efektivitas Pendekatan Deep Learning Terhadap Kontrol Diri Remaja Dalam Menggunakan Internet (Nur Sya'ban Ratri Dwi Mulyani, Siti Partini Suardiman)

\section{DAFTAR PUSTAKA}

American Psychological Association. (2015). Internet Use; Internet use can provide positive and negative health information for children and adolescents. ( Proquest Family Health 1-3). Proquest document Link.

Baumeister, R. F. \& Tierney, J. (2011). Willpower Rediscovering The Greatest Human Strength. New York: The Pinguin Press.

Baumeister, R. F., Vohs, K. D., \& Tice, D. M. (2007). The Strength Model of Self-Control. Journal of Psychological Science. Volume 16 No 6 Page 351-355

Brier, N. M. (2015). Enhancing Self Control in Adolescents Treatment Strategies Derived from Psychological Science. Routledge: New York.

Brier, N. M. (2015). Enhancing Self Control in Adolescents Treatment Strategies Derived from Psychological Science. Routledge: New York.

Casey, B. J., \& Caudle, K. (2013). The Teenage Brain : Self Control. Psychological Science Vol 22 No 2 page 82-87. DOI: $10.1177 / 0963721413480170$

Dariyo, A. (2004). Psikologi Perkembangan Remaja. Bogor: Halia.

Dewi, S. (2012). Hubungan antara Self Control dengan Internet Addiction pada Mahasiswa. Jurnal Psikologi Pendidikan FIP UNNES. Vol 1 No 1.

Duckworth, A. L., Kim, B., \& Tsukayama, E. (2013). Life stress impairs self-control in early adolescence. Journal of Psychology University of Pennsylvania, Volume 3 Article 608 pp 112. doi: 10.3389/fpsyg.2012.00608

Entwistle, N. (2000). Promoting Deep Learning Through Teaching and Assessment: Conceptual Frameworks and Educational Contexts. Paper to be Presented at TLRp Conference, Leicester, hlm 1-12.

Entwistle, N. (2000). Promoting Deep Learning Through Teaching and Assessment: Conceptual Frameworks and Educational Contexts. Paper to be Presented at TLRp Conference, Leicester, hlm 1-12.

Fry, H., Ketteridge, S., \& Marshall, S. (2009). A handbook for teaching and learning in higher education enhancing academic practice third edition. New York: Routledge

Ganda, F., Ngwakwe, C.C., Ambe, C. M. (2014). Independent Research and a Deep Approach to Learning of Accounting Concepts: Students' View. Mediterranean Journal of Social Sciences Vol 5 No 6. Hal. 75-89, ISSN 2039-2117 (online), Doi:10.5901/mjss.2014.v5n6p75

Ghufron, M. N., \& Risnawita S., R. (2010). Teori-teori Psikologi. Yogyakarta: Ar-Ruzz Media.

Haditono, S. R., dkk. (2002) Psikologi Perkembangan Pengantar dalam Berbagai Bagiannya. Yogyakarta: Gadjah Mada University Press.

Hasnora, H.N. , Ahmadb, Z. , Nordin, N. (2013). The Relationship Between Learning Approaches And Academic Achievement Among Intec Students, Uitm Shah Alam. Procedia - Social and Behavioral Sciences 90, hal 178 - 186, doi: 10.1016/j.sbspro.2013.07.080

Hasnora, H.N. , Ahmadb, Z. , Nordin, N. (2013). The Relationship Between Learning Approaches And Academic Achievement Among Intec Students, Uitm Shah Alam. Procedia - Social and Behavioral Sciences 90, hal 178 - 186, doi: 10.1016/j.sbspro.2013.07.080

Hermida, J. (2015). Facilitating Deep Learning. Canada: Apple Academic Press

Highfield, J. J. B. (2012). Internet Use and Self-Control in Children In Grades 4 Through 6. Thesis. The Faculty at Humboldt State University.

Jensen, E dan Nickelsen, L. (2008). Deeper Learning 1 Strategi untuk DELC. Indeks: Jakarta 
Kim, S. (2011). The Effects Of Internet Use On Academic Achievement And Behavioral Adjustment Among South Korean Adolescents:Mediating And Moderating Roles Of Parental Factors. Disertasi, M.A. Drexel University.

Larasati, M.A. \& Budiani, M.S. (2014). Hubungan antara Kontrol Diri dengan Pembelian Impulsif Pakaian pada Mahasiswi Psikologi Universitas Negeri Surabaya yang Melakukan Pembelian secara Online. Jurnal Character. Volume 02 Nomor 3.

Lublin, J. (2003). Deep, Surface, and Strategic Approach to Learning. Dublin: UCD.

Moon, J. A. (2005). A Handbook of reflective and experiential learning theory and practice. New York: Routledge Farmer

Moon, J. A. (2005). A Handbook of reflective and experiential learning theory and practice. New York: Routledge Farmer

Moore, P. J., \& Telfer, R. A. (1990). Approaches to Learning: Relationships with Pilot Performance. Journal of Aviation/Aerospace Education \& Research, Vol 1 No 1. Hal 1-16. https://doi.org/10.15394/JAAER.1999.1000

Muraven, M. \& Slessareva, E. (2003). Mechanisms of Self-Control Failure: Motivation and Limited Resources. Personality and Social Psychology Bulletin, Vol. 29 No. 7 page 894-906. DOI: $10.1177 / 0146167203253209$

Nęcka, E. (2015). Self Control Scale AS-36: Construction and validation study. Polish Psychological Bulletin, vol. 46(3) 488-497. DOI - 10.1515/ppb-2015-0055

Offir, B., Lev, Y., \& Bezalel, R. (2008). Surface and deep learning processes in distance education: Synchronous versus asynchronous systems. Journal of Computers \& Education ed 51. Hal $1172-1183$

Panji, A. (2014). Hasil Survei Pemakaian Internet remaja Indonesia. Diambil pada tanggal 31 Juli 2015, dari

http://tekno.kompas.com/read/2014/02/19/1623250/hasil.survei.pemakaian.internet.remaja.ind onesia

Poerwanti, E. \& Widodo, N. (2002). Perkembangan Peserta Didik. Malang: Universitas Muhammadiyah Malang.

Pung, P. W., Yaacob, S. N., Baharudin , R., \& Osman, S. (2015). Low Self-Control, Peer Delinquency and Aggression among Adolescents in Malaysia. Asian Social Science, Vol. 11, No. 21 pp 193202, ISSN 1911-2017, E-ISSN 1911-2025, doi:10.5539/ass.v11n21p193

Seam, R. (2014). How New Paedagogis Find Deep Learning. Canada: Pearson

Sigelman, C. K., \& Rider, E. A.. (2018). Life Span Human Development. Cengage Learning: USA.

Sukarno. (2013). Conducting Deep English Learning in Implementing The Curriculum 2013: A Genuinely Challenging Challenge. Proceedings $1^{\text {st }}$ Educational Linguistic Conference, UNY, $1-466$.

Suler, J. (2005). Adolescents in Cyberspace The Good, the Bad, and the Ugly. Psychology of Cyberspace, Vol 1 No 5 page 1-8

Suprapto. (2006). Peningkatan Kualitas Pendidikan Melalui Media Pembelajaran Menggunakan Teknologi Informasi Di Sekolah. Jurnal Ekonomi dan Pendidikan UNY, Volume 3 No 1: halaman 34-41.

Syukron, B. (2014). Deep Dialogue / Critical Thinking Konsep Solusi Pembelajaran Inovatif). TAPIS Vol 14 No 02 hal 291-309. Haditono, S. R., dkk. (2002) Psikologi Perkembangan Pengantar dalam Berbagai Bagiannya. Yogyakarta: Gadjah Mada University Press. 
Efektivitas Pendekatan Deep Learning Terhadap Kontrol Diri Remaja Dalam Menggunakan Internet (Nur Sya'ban Ratri Dwi Mulyani, Siti Partini Suardiman)

Tangney, J. P., Baumeister, R. F., \& Boone, A. L. (2004). High Self-Control Predicts Good Adjustment, Less Pathology, Better Grades, and Interpersonal Success. Journal of Personality 72 (2). Page 271-322

Weir, K. (2012). What You Need to Know about Willpower: The Psychological Science of Self-Control. Washington D.C. : American Psychological Association.

Young, K. S. (1999). Internet Addiction: Symptoms, Evaluation, And Treatment (versi elektronik). Sarasota, volume 17, Proffesional Resource Press 